\title{
EFFECT OF DEAD SEA WATER ON DURABILITY, STRENGTH, FLEXURE AND BOND ON HARDENED CONCRETE.
}

\author{
Hamadallah AL-Baijat \\ Associate Professor, Civil Engineering Department, \\ Tafila Technical University, Tafila, Jordan. \\ On leave Sabbatical year at Civil Engineering Department, \\ American University of Madaba, Jordan
}

\begin{abstract}
The purpose of this research is to study on the effect of the Dead Sea water on concrete structures. The normal concrete is usually mixed and cured with fresh water in order to protect the concrete from alkali attack which may lead to expansion and deterioration and finally loss of durability of concrete. Compressive strength, absorption, corrosion of steel, bond stress, and flexural stress were investigated in fresh and saline (Dead Sea) waters. Salt durability, compressive strength, flexural stress, and bond stress significantly decreased after exposure of concrete to Dead Sea saline water.
\end{abstract}

Key words: Dead Sea, Salt Water, Corrosion, Durability, Bond Stress, Flexural Stress, Compressive Strength.

Cite this Article: Hamadallah AL-Baijat, Effect of Dead Sea Water on Durability, Strength, Flexure and Bond on Hardened Concrete. International Journal of Advanced Research in Engineering and Technology, 10(4), 2019, pp. 102-112.

http://iaeme.com/Home/issue/IJARET?Volume=10\&Issue $=4$

\section{INTRODUCTION}

Concrete is a brittle and porous material. Concrete is used in buildings in different ways and combined with steel. Steel is affected by concrete water which may cause corrosion. In this research, the principal researcher will conduct an experimental study in order to investigate the effect of Dead Sea water (Salty water) on concrete durability, Absorption, Compressive strength, Bond stress. Flexural stresses, and Corrosion of steel.

Many buildings such as hotels, restaurants, houses, and some building represent churches (Baptist site) at Jordan valley. The author visits several buildings in the dead Sea area for deterioration assessment, and conducting visual inspection. The result of the inspection show a lot of deterioration to the concrete elements such as walls, concrete pipes, box culvert, wing 
walls, foundation of building, and rigid side walk. Heavy deterioration was noticed all over the structural element as a result of exposure to the effect of dead sea water.

It is usual in concrete industry to use the same clean and drinkable water used for mixing the concrete as curing water. The presence of salt in the water is considered harmful to the concrete since it induces steel corrosion and some other severe consequences such as Efflorescence which is a white deposit appears on the concrete surface. On the other hand sulfate attack is a main concern since it starts damaging the concrete from edges toward inside and causing severe internal stresses. Another concern is the formation of the Ettringite (Calcium Slfo Aluminate) which expand in volume and disrupt the hardened concrete. Magnesium sulfate has a more damaging effect than other sulfate because it leads to the decomposition of the hydrated calcium silicates. Hydrated magnesium silicate is eventually formed and has no binding properties.

The author will use the Code available in civil engineering such American concrete institute, (ACI), American standard of testing material, (ASTM), American association of state highway transportation official, (AASHTO). American institute of steel construction, (AISC), and the Jordanian code of concrete structure.

The dead sea concentration is about $335 \mathrm{ml} /$ liter as a salt. The types of these salts are $\mathrm{MgCL}=14.5 \%, \mathrm{NaCl}==7.5 \%, \mathrm{CaCL} 2=3.8 \%, \mathrm{MgBr} 2=0.5, \mathrm{KCL}=1.2 \%$, and the remaining is water (9). Since concrete has high porosity, dead sea water easily to penetrates in to concrete and due to high concentration of different types of salt, concrete will deteriorate significantly. Durability of concrete to sustain weathering effect will be decreased down. This comprehensive study is trying to investigate environmental solution to keep durability in the level to maintain concrete strength. The outcome of this research will contribute highly to the art of concrete industry in the civil engineering discipline and enhancing the knowledge of the engineers in construction site nearby dead sea and in the office design. This research will open the knowledge to all, who are working in concrete constructions, office design and students.

The following authors investigated topic related one way or other to this research: Basem K. Moh'd: Conducted a research on the durability of limestone which is the most dominant construction material in Jordan. It is used in most stone building in the country. A twenty specimens representing ten building limestone were cut into 3-4 cubes and subjected to 15 cycles of immersion in the Dead Sea water and drying in an oven at $105 \mathrm{C}^{\circ},(10)$.

Akinsola Olufemi Emmanuel et al 2012. Conducted a study on compressive strength and reported that the sample casted and cured with ocean and lagoon water slowly showed increase in its strength, but it was low when compared with fresh water concrete element (11).

Falah M.Wegian 2010 investigated the effects of mixing and curing concrete with sea water on the compressive strength, tensile, flexural and bond strengths and reported that there are increases of strengths of concrete mixed and cured in sea water at early ages and a definite decrease for ages more than 28 days and up to 90 days.(12)

O.O.Akinkurolere et al 2007 studied the influence of salt water on compressive strength of concrete and reported that the mixing and curing with salt water increases the compressive strength rapidly and the strength was still increasing at 28 days (13).

Md. Moinul Islam et al 2012 reported that a compressive loss of about 10\% when the concrete specimens made and cured with sea water compared to plain water mixed and cured concrete. (6)

M.I. Retno Susilorini et al 2005 reported on the performance of early age concrete with sea water curing of 7 days and 14 days is higher than those cured by plain water in respect of compressive strength. (14) 
E.M. Mbadike et al 2011 investigated the effect of salt water in the production of concrete and reported $8 \%$ strength reduction. (15)

\section{METHODOLOGY AND METHOD}

The following specimens (cubes, beams, cubes with bars for bond stress, steel bars for corrosion, Dead Sea water) were prepared to investigate the durability of concrete, compressive strength, flexural strength, bond stress, and corrosion of steel, density and absorption under the effect of Dead Sea water cycles.

The following mechanical properties of concrete were conducted.

\subsection{Compressive strength}

The compressive strength was conducted according to BS-EN. 12390-3:09. The author prepare 9 cubes $150 \mathrm{~mm} \times 150 \mathrm{~mm} \times 150 \mathrm{~mm}$, these cubes were curing in fresh water for 28 days, after 28 days of age the 9 cubes were divided into three groups as follows:

1. Three cubes for determination of f'c.

2. Three cubes to be immersion in Dead Sea water for 28 days.

3. Three cubes were subjected to 25 cycles, cubes were submerge in Dead Sea water for 24 hours, then drying in the oven $110^{\circ} \mathrm{C}$ inside the oven for another 24 hours. The weight will be obtained for both cases. (This is what we called one cycle).

\subsubsection{Flexural stresses}

The flexural Strength were conducted according to ASTM, C-78 .Nine beams were prepared $100 \mathrm{~mm} \times 100 \mathrm{~mm}$ x $500 \mathrm{~mm}$. Three beams were immersion in fresh water for 28 days, another three beams go to dead sea water after of 28 days of age in fresh water. Three beams of age 28 days in fresh water subjected to 18 cycles. (samples in dead sea water for 24 hours and in oven for another 24 hours).

\subsubsection{Bond stresses}

The bond stress investigates the pull-out steel specimens from concrete cubes. Nine cubes were prepared $150 \mathrm{~mm} \times 150 \mathrm{~mm} \times 150 \mathrm{~mm}$ with $\varnothing 16 \mathrm{~mm}$ steel bar and $500 \mathrm{~mm}$ length placed in the middle of cube. The test conducing according to ASTM C1583. Three cubes with steel bars submerged in fresh water for 28 days and tested, three cubes also with steel bar submerged in dead sea water for 28 days and tested after 28 days in fresh water. The last three cubes with bars were submerged in fresh water going to be under 20 cycles, then the specimens were tested.

\subsubsection{Corrosion of steel}

Three samples of steel bars were immersion in three liters jars filled with Dead Sea Water, all samples were known diameters and weight before submerged in dead sea water. The losses of weight was recorded at $3,9,12$, and 20 months.

\subsubsection{Density of concrete}

The weight of the samples was recorded and volume. The density of concrete elements was calculated before and after specimen submerged in dead sea water and going under cycles. 


\subsubsection{Absorption}

The absorption of the specimens after 20 cycles was very small because of salt was entered in the concrete samples pours.

There were also, 9 samples for each 7, 14, and 21 days with $250 \mathrm{~kg}$ of cement per $\mathrm{m}^{3}$. But the effect of dead sea water on concrete not much especially at early ages of specimen. However, the cement proportion was increase to be $350 \mathrm{~kg} \mathrm{per}^{3}$.

\section{RESULTS TESTES AND DISCUSSION}

The results of the compressive strength were shown as in Table 1, Figure 1, and Figure 1-a shows the laboratory test.

Table 1 Strength of Concrete cubes in Fresh water versus Dead Sea Water and Cycles (in dead sea water 24 hours then in oven $110 \mathrm{C}^{\circ}$ for 24 hours)

\begin{tabular}{|c|c|c|c|c|c|c|}
\hline $\begin{array}{c}\text { No. of } \\
\text { sample }\end{array}$ & $\begin{array}{c}\text { In fresh } \\
\text { water } \\
\text { Load kN }\end{array}$ & Stress MPa & $\begin{array}{c}\text { In dead sea } \\
\text { Load kN }\end{array}$ & Stress MPa & $\begin{array}{c}\text { Cycles in oven 24h } \\
\text { and in dead sea 24h } \\
\text { Load kN }\end{array}$ & Stress MPa \\
\hline 1 & 702 & 31.2 & 487.3 & 21 & 450 & 20 \\
\hline 2 & 720 & 32 & 501 & 22.2 & 461 & 20.4 \\
\hline 3 & 738 & 32.8 & 496 & 22.05 & 456 & 20.2 \\
\hline
\end{tabular}

From Figure 1 and Table 1 the stresses were decreased by an average of $36.7 \%$, the load and stresses decrease significantly as the specimen expose to dead sea and cycles.

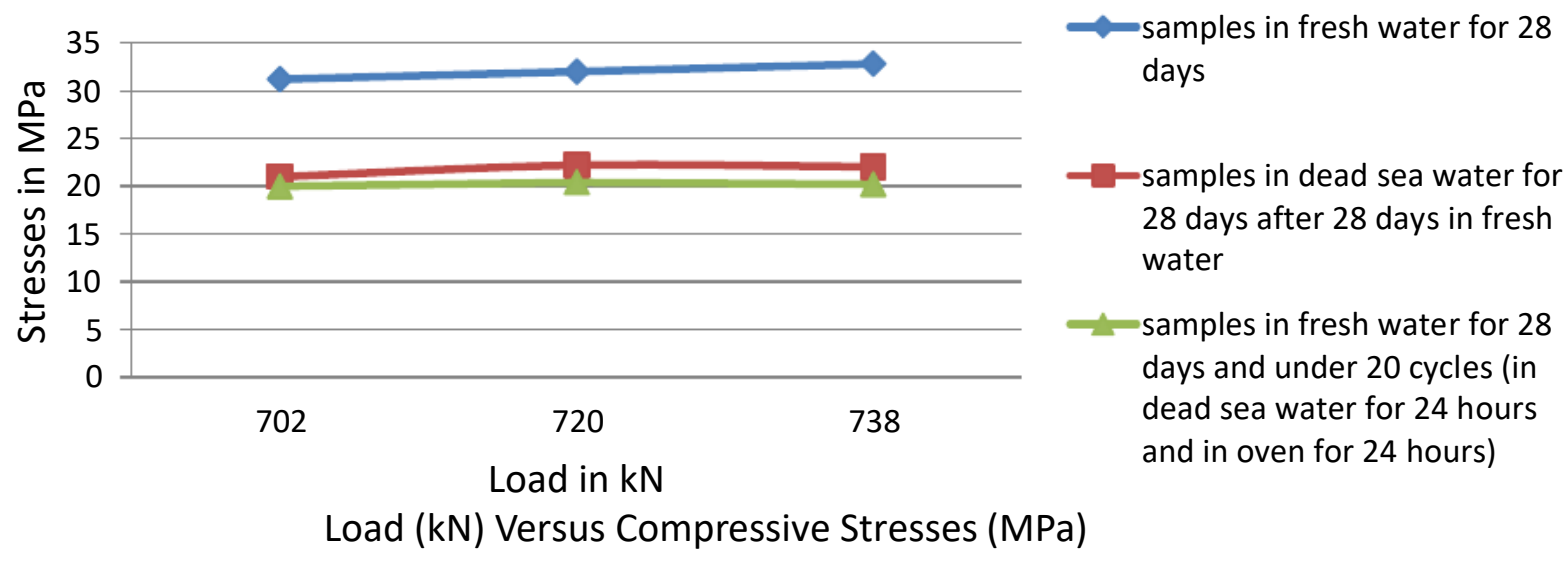

Figure 1: Stresses (MPa) for Three Different Cases versus Load $(\mathrm{kN})$ 


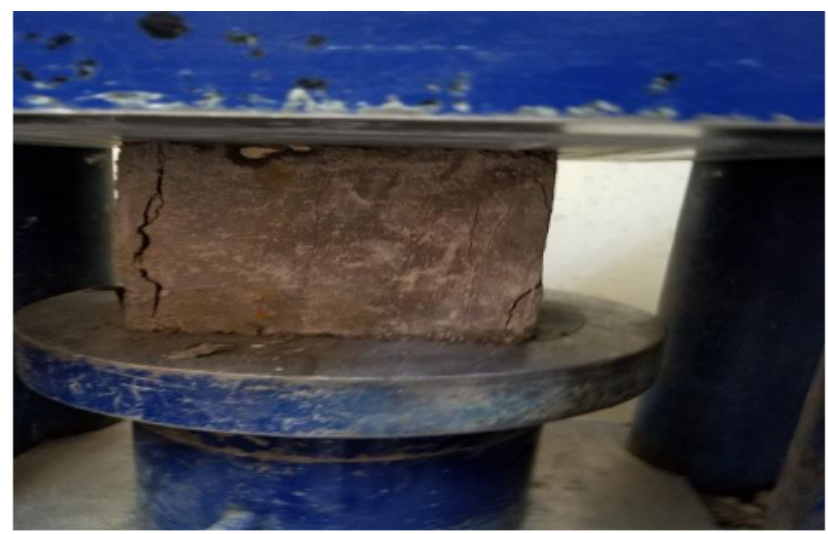

Figure 1-a: The compressive Strength for the Cycle case.

2) The results of flexural stress shown in Table 2. The proportion of cement was $250 \mathrm{~kg}$ per $\mathrm{m}^{3}$

The specimen beams were tested at age of 14,21 , and 28 days as reference beams, same number of beams were investigated under effect of cycles. The decreasing in stresses were $40 \%, 27 \%$, and $22 \%$ for 28 days, 21 days, and 14 days respectively. This results as in Table 2 , Table 2-a, and Figure 2 shows the deterioration of the material as a result of dead sea water cycles. Figure 2-a represent the specimen under flexural test.

Table 2 Flexural stress for Reference beams without cycle versus beams with cycles for $250 \mathrm{~kg}$ cement per $\mathrm{m}^{3}$.

\begin{tabular}{|l|l|l|l|l|l|l|l|}
\hline $\begin{array}{l}\% \\
\text { Reduction }\end{array}$ & $\begin{array}{l}\text { Flexural } \\
\text { stress for } \\
\text { reference } \\
\mathrm{MPa}\end{array}$ & Load kN & $\begin{array}{l}\text { Sample } \\
\text { No }\end{array}$ & Age days & Load kN & $\begin{array}{l}\text { Flexural } \\
\text { stress } \\
\mathrm{MPa}\end{array}$ & $\begin{array}{l}\text { Average } \\
\text { stress for } \\
\text { cycles } \\
\mathrm{MPa}\end{array}$ \\
\hline 40 & 4.27 & 9.5 & $\begin{array}{l}12 \\
14\end{array}$ & $\begin{array}{l}28 \\
28\end{array}$ & $\begin{array}{l}5.2 \\
6.2\end{array}$ & $\begin{array}{l}2.34 \\
2.79\end{array}$ & 2.56 \\
\hline 27 & 1.91 & 5.7 & $\begin{array}{l}15 \\
8\end{array}$ & $\begin{array}{l}21 \\
21\end{array}$ & $\begin{array}{l}4.0 \\
4.5\end{array}$ & $\begin{array}{l}1.8 \\
2.03\end{array}$ & 1.91 \\
\hline 22 & 1.4 & 3.2 & 5 & 14 & 2.7 & 1.22 & 1.1 \\
\hline
\end{tabular}

Table 2-a Comparison of Flexural stresses between Reference Concrete and Samples under cycles in Dead Sea Water

\begin{tabular}{|c|c|c|c|c|c|c|c|}
\hline Sample No & $\begin{array}{c}\text { Load } \\
(\mathrm{kN})\end{array}$ & $\begin{array}{c}\text { Stresses in } \\
\text { fresh water } \\
\mathrm{MPa}\end{array}$ & Load $(\mathrm{kN})$ & $\begin{array}{c}\text { Stresses in } \\
\text { dead sea } \\
\text { water MPa }\end{array}$ & $\begin{array}{c}\text { Load } \\
(\mathrm{kN})\end{array}$ & $\begin{array}{c}\text { Stresses after } \\
\text { cycles in } \\
\text { dead sea } \\
\text { water MPa }\end{array}$ & $\begin{array}{c}\text { \% losses of } \\
\text { stresses after } \\
\text { cycles }\end{array}$ \\
\hline 1 & 14.4 & 4.27 & 12.25 & 3.67 & 10.55 & 3.19 & 25.29 \\
\hline 2 & 14.2 & 4.21 & 11.98 & 3.59 & 10.45 & 3.17 & 24.7 \\
\hline 3 & 14. & 4.14 & 11.8 & 3.51 & 10.2 & 3.09 & 25.36 \\
\hline
\end{tabular}




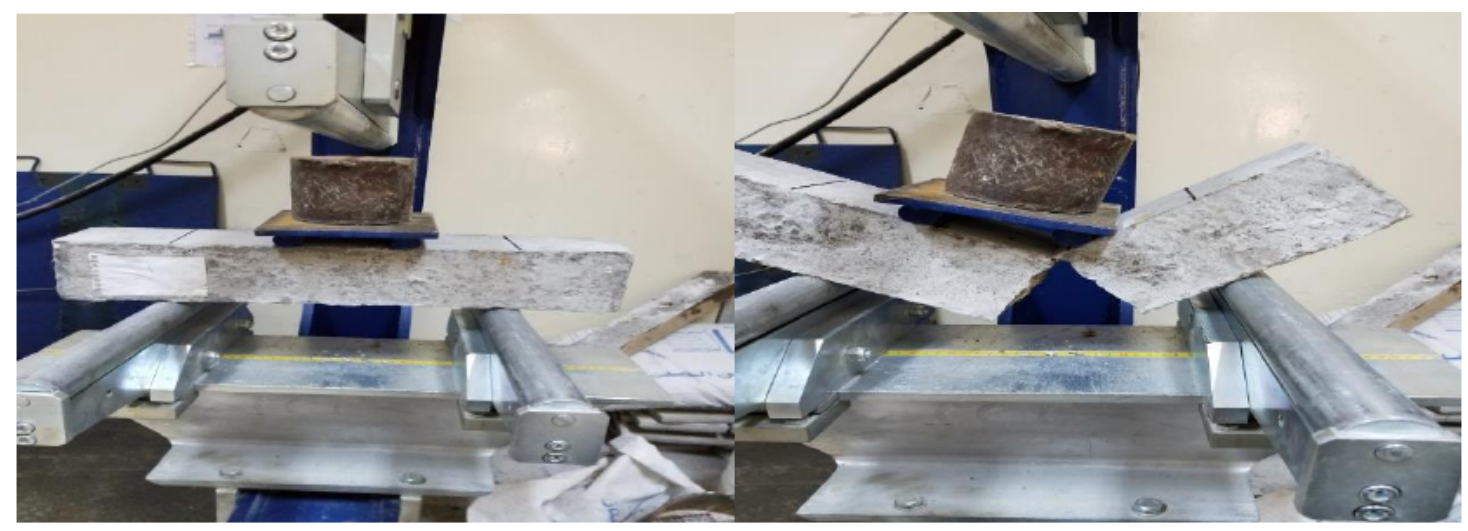

Figure 2-a Flexural Stress Test at Two Points.

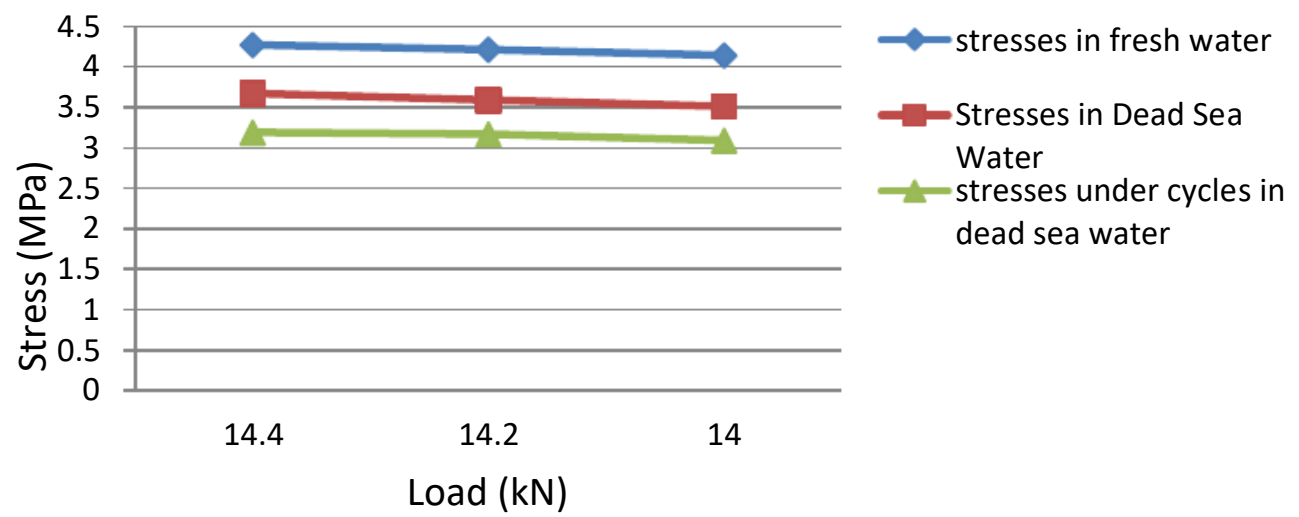

Figure 2 Load kN versus Flexural Stresses MPa for Samples in Fresh Water, Dead Sea Water, and Expose to Cycles.

3) Bond stresses; Table 3, Figure 3 illustrate the comparison of bond stresses between samples in fresh water, dead sea water, and cycles in dead sea and oven. The laboratory test for the comparison of bond stresses as in Figure 3-a.

Table 3 Comparison of bond stresses between normal Concrete and Samples under cycles in Dead Sea Water

\begin{tabular}{|c|c|c|c|c|c|c|c|}
\hline Sample No & Load $(\mathrm{kN})$ & $\begin{array}{c}\text { Stresses in } \\
\text { fresh water } \\
\mathrm{MPa}\end{array}$ & Load $(\mathrm{kN})$ & $\begin{array}{c}\text { Stresses in } \\
\text { dead sea } \\
\text { water MPa }\end{array}$ & Load $(\mathrm{kN})$ & $\begin{array}{c}\text { Stresses after } \\
\text { cycles in } \\
\text { dead sea } \\
\text { water MPa }\end{array}$ & $\begin{array}{c}\text { \% losses of } \\
\text { stresses after } \\
\text { cycles }\end{array}$ \\
\hline 1 & 34 & 4.51 & 28 & 3.71 & 24.65 & 3.2 & 29 \\
\hline 2 & 32.8 & 4.35 & 27.84 & 3.61 & 23.95 & 3.13 & 28 \\
\hline 3 & 32.3 & 4.29 & 27.65 & 3.58 & 23.3 & 3.10 & 27.7 \\
\hline
\end{tabular}




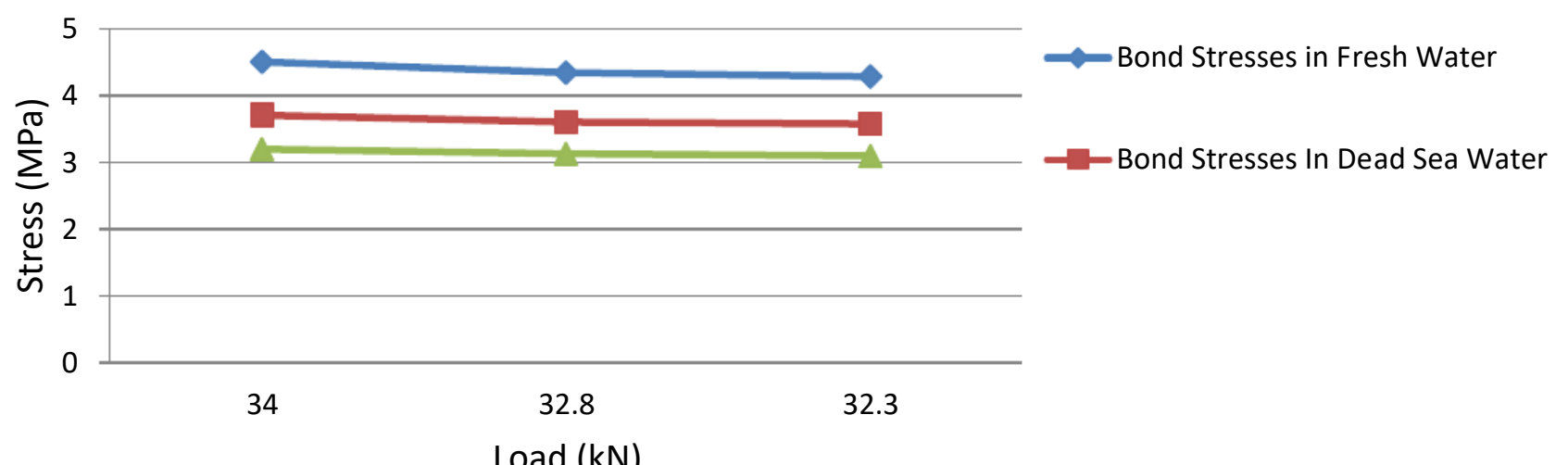

Figure 3: Load kN versus Stresses for Three Cases

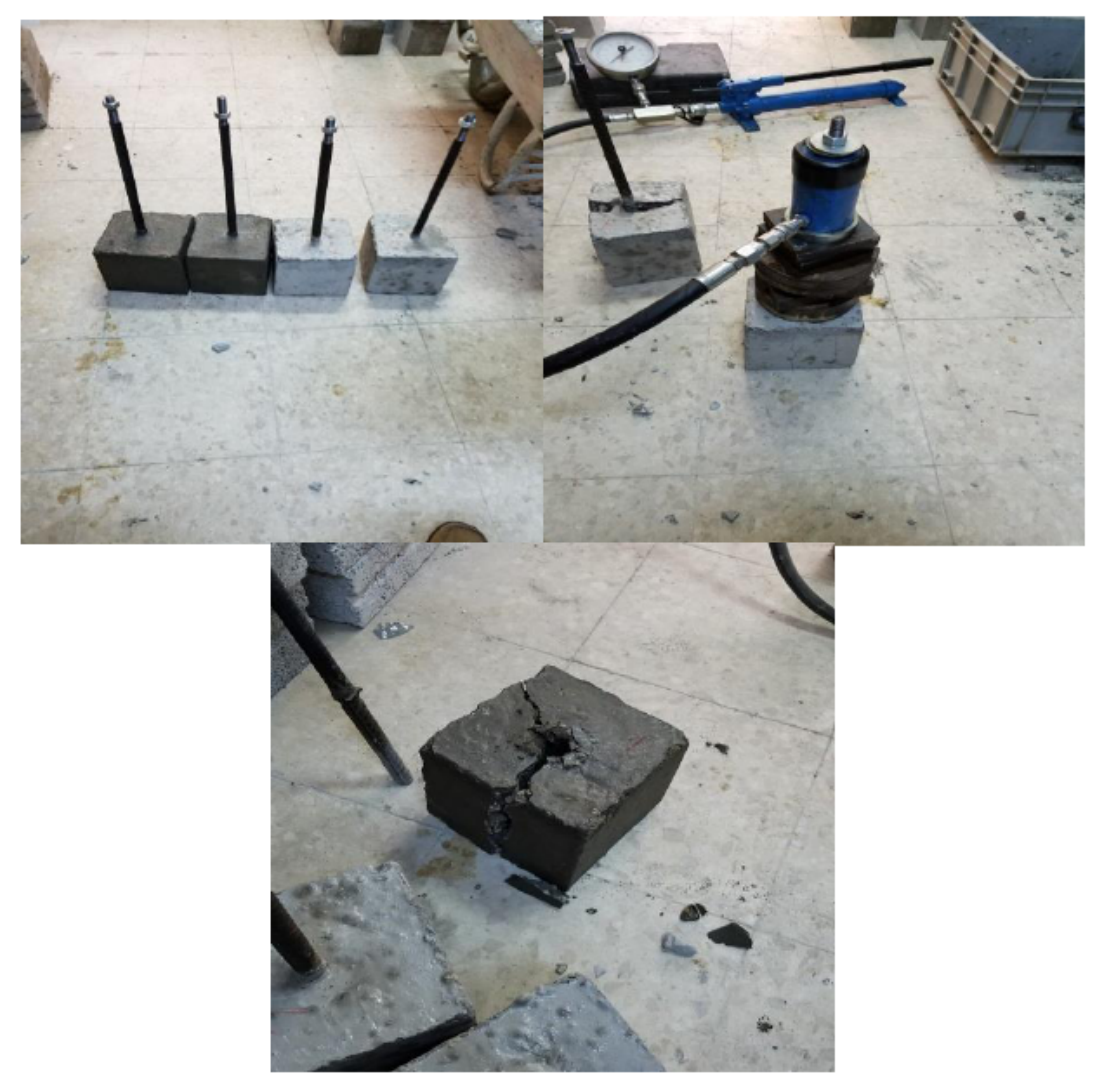

Figure 3-a Bond Stress Test for Specimens in Fresh Water and Dead Sea Water.

\section{4) Steel Corrosion:}

Three bars of steel were completely submerged in Dead Sea water to investigate the losses of the weight of the samples, the results were shown in Table 4 . When the steel bars immersion in Dead Sea water jars, it was noticed that; the color of water start to changing to brown as the time elapses, by the end of three, six, nine, twelve and eighteen months. The color rapidly increase to word brown. This result confirm the increase losses in steel bars as a result of exposure to Dead Sea water. The corrosion of steel bars immersion in dead sea water indicated in Figure 4.Table 4, and Figure 4-a: represent the result of the tests. 
Table 4 Corrosion of steel bars submerged in Dead Sea water Versus Time in Months.

\begin{tabular}{|c|c|c|c|c|}
\hline Sample No & $\begin{array}{c}\text { Weight of sample } \\
\text { before submerged } \\
\text { in dead sea g }\end{array}$ & $\begin{array}{c}\text { Weight of sample } \\
\text { after submerged in } \\
\text { dead sea for 9 } \\
\text { months g }\end{array}$ & $\begin{array}{c}\text { Weight of sample } \\
\text { after submerged in } \\
\text { dead sea for 12 } \\
\text { months g }\end{array}$ & 20 month \\
\hline & 0 & 9 & 12 & 20 \\
\hline 1 & 120 & 117.5 & 116.5 & 115 \\
\hline 2 & 108.5 & 107 & 105.4 & 105 \\
\hline 3 & 106 & 102 & 100.5 & 100 \\
\hline
\end{tabular}

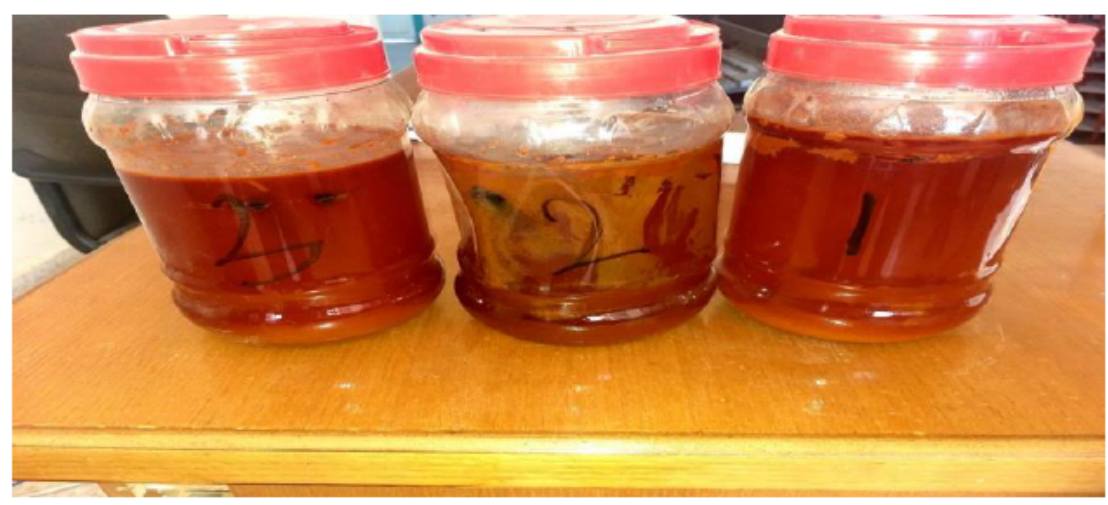

Figure 4: Corrosion of Steel Bars under immersion in Dead Sea water jar.

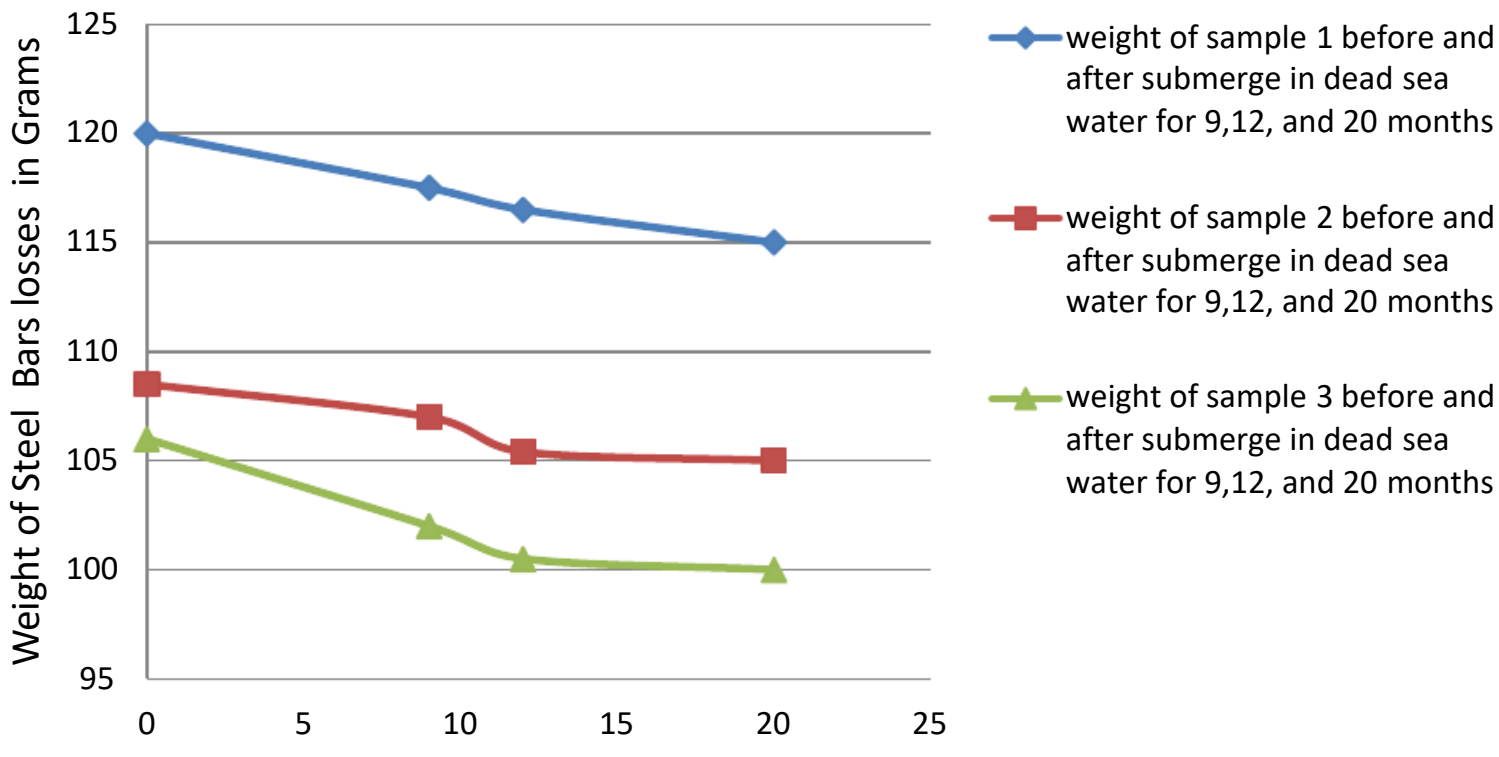

Duration of Submerge in Dead Sea water in Months

Figure 4-a Losses in Steel Bars Versus Immersion Time in months in Dead

\section{Sea Water}

5) The density of submerged samples in dead sea water and exposure to 16 cycle. The density was increase from $2332 \mathrm{~kg} / \mathrm{m}^{3}$ to $2466 \mathrm{~kg} / \mathrm{m}^{3}$ with $5.7 \%$. This increment, reflect the availability of porosity of the mix and as a result of absorption of dead sea water.

6) Absorption 
The weight of samples almost doesn't changed much. The absorption is less the $1 \%$, as a result of closing the porosity of the mix.

It was noticed by visual inspection of specimens (cubes, beams, steel bars, and cubes with steel bars) that the dead sea water has significant deterioration on steel bars and on concrete element. Heavy severe damage to concrete and losses of steel weight.

The beams, cubes, and cubes with steel bars cycles in dead sea water and oven were shown in Figure 5-a,b,c,and d. It was noticed that the concrete specimens which expose to dead sea water and cycle intended to loss it s durabilty, srength and bond stress, while density increased.

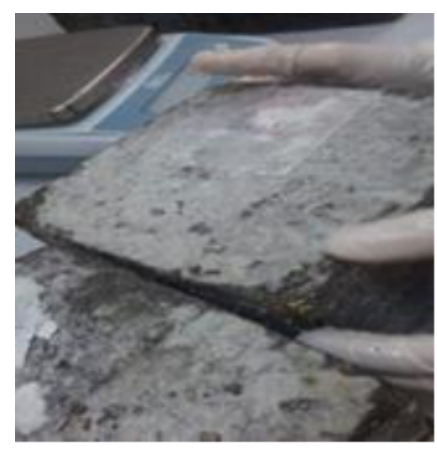

Figure 5-a

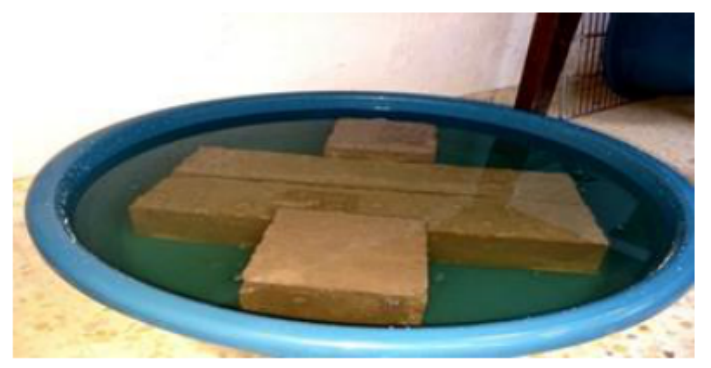

Figure 5-c

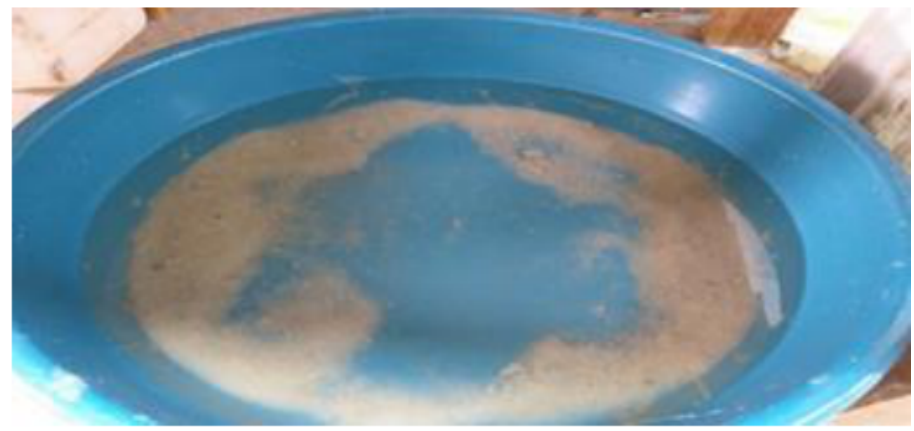

Figure 5-b

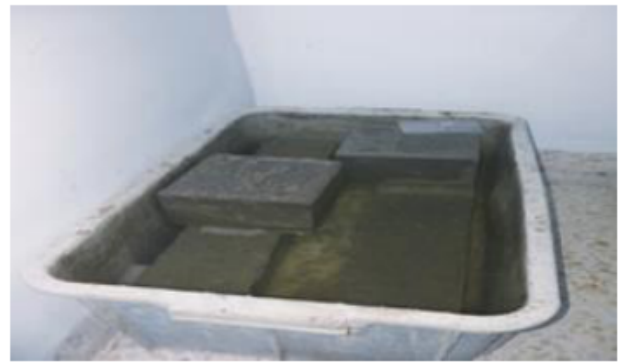

Figure 5-d

Figure 5-a Shows the Heavy Deterioration of the Concrete Samples in Dead Sea cycles, b: Shows the Severe and Losses of Concrete Particles, $\mathrm{c}$ and d: Beams and Cubes under Cycles in Dead Sea Water.

\section{CONCLUSION AND RECOMMENDATIONS:}

1. It was noticed that, the strength of concrete increased as the age of sample increase than 28 days.

2. The durability, strength, flexural, and bond stress of concrete were decrease down when immersion in dead sea water and decrease more after exposure to cycles.

3. Losses in steel bars weight during submerged in dead sea water and the losses increase as the period of immersion increase.

4. The concrete elements (cubes, beams, and cubes with and without bars) were heavy deterioration after exposure to cycle in dead sea water.

5. The author strongly recommended, the use of special material to isolate the foundation of building in dead sea area to prevent chloride and sulfate attack concrete elements.

6. Conducting research on long term, to find the effect of dead sea on concrete for more than three months. 


\section{ACKNOWLEDGMENTS}

The author would like to appreciate the American University of Madaba for funding this research during the on-leave sabbatical year from Tafila Technical University for the year of 2016/2017.

\section{REFERENCES}

[1] Ernasto T. Anacta., "Effect of salt contaminated mixing water and aggregates on time to initiate rear corrosion in concrete". International Journal of Scientific and Engineering Research, Vol. 4, April-2013.

[2] Bassam Mahasneh. University of Mutaa-civil engineering department. "Dead sea as a soil improvement agent". ETGE.

[3] Preeti Tiwari et al. "Effect of salt water on compressive strength of concrete". International Journal of Engineering Research and Applications. Vol.4 Issue 4, April 2014, pp38-42.

[4] T. Jena and K. C. Panda, Compressive Strength and Carbonation of Sea Water Cured Blended Concrete. International Journal of Civil Engineering and Technology, 8(2), 2017, pp. $153-162$

[5] Hsien K. liu et al., "Effect of seawater on compression strength of concrete". Composites Science and Technology. Vol 62, Issue 16, December 2002. Pp 2131-2141.

[6] Rakesh A. More et al. "Effect of different types of water on compressive strength of concrete". International Journal on Emerging Technologies". Vol. 5, Issue 2, pp 40-50 October, 2014.

[7] S. Thadela, Raja Sekhar Dondapati and V. V. Rao Process Simulation of Vacuum Desalination Systems for Producing Potable Drinking Water from Saline Sea Water. International Journal of Mechanical Engineering and Technology, 8(7), 2017, pp. 18811891.

[8] Md. Moinul Islam, et al, "Strength of concrete using slag with cement in sea water environment". Journal of civil engineering. (IEB), 32 (2) (2010) 129-140.

[9] W. Sai Deepak, G. Tirupathi Naidu "Effect on compressive strength of concrete using sea sand as a partial replacement for fine aggregate" International Journal of research in engineering and technology. eISSN:2319-1163; Pissn:2321-7308.

[10] P. Krishanam Raju et al, "An investigation on strength of concrete for marine works using OPC and sea water" SSRG Journal of civil engineering (SSRG-IJCE) Vol.1 Issue 1-Feb 2014.

[11] Sami Masadeh et al "Electromechanical chloride extraction from concrete structure exposed to dead sea water" ACTA technical corviniensis-bulletin of engineering. Tome VII (2014).

[12] Shivani Kapoor and Er. Sandeep Nasier, Utilization \& Effects of Crown Caps On Strength Properties of Concrete (Including Sea Water), International Journal of Civil Engineering and Technology, 9(7), 2018, pp. 210-218.

[13] Basem K. Moh'd, "Effect on limestone of 15 cycles of immersion in dead sea water". Journal of applied sciences 6(12):2682-2684,2006.

[14] Akinsola Olufemi Emmanuel., et al, "Investigation of salinity effect on compressive strength of reinforced concrete". Journal of sustainable development, Vol,5, No.6; 2012. 
[15] Falah M. Wegian; "Effects of sea water for mixing and curing on structural concrete study".The IES Journal part A: civil and structural engineering, Vol.3, No. 4, November 2010, 235-243.

[16] O.O. Akinkurolere; et al, "The influence of salt water on the compressive strength of concrete", Journal of engineering and applied science 2(2) 112-115,2007.

[17] M.I. Rento Susilorini., et al. "The performance of early age concrete with sea water curing". Journal of coastal department, Vol. 8, No.2, February 2005, 85-95.

[18] E. M. Mbadike., et al," Effect of salt water in the production of concrete", Nigeria journal of technology, Vol 30, No.2, Jane 2011. 